\title{
ASSESSMENT OF BIOMASS UTILIZATION FOR ENERGY PRODUCTION FROM AGRICULTURAL RESIDUE
}

\author{
Astrida Miceikienè ${ }^{1}$, Rita Bužinskiené² \\ ${ }^{1}$ Prof. dr. Vytautas Magnus University, Universiteto str. 10, Kaunas, Lithuania \\ Email address: astrida.miceikiene@vdu.lt \\ ${ }^{2}$ Assoc. prof. dr. Siauliai State College. Ausros al. str. 40, Siauliai, Lithuania \\ Email address: r.buzinskiene@svako.lt
}

Received 1611 2020; Accepted 09122020

\begin{abstract}
This study discusses biomass potential utilization for energy production from primary and secondary agriculture residue assessment. The purpose of the research - to carry out an assessment of the biomass utilization potential from agricultural residue. The methodology based on analysing statistical data of Lithuania, to estimate the biomass utilization possibilities from agriculture residue. The research methods involve the methodology for the assessment using the mathematics equations and also based on methods of analysis, synthesis and others to achieve to solve the problem of competition between the food industry and agriculture sectors for the food gap in the near future. The authors determined that the potential energy yield from primary agriculture residue is higher than secondary agriculture residue and primary residue utilization for energy production is more useful than secondary residue. The problem with these results discloses that secondary agriculture residue utilization for bioenergy production needs more support with the development of knowledge and skills in Lithuania, especially should apply to attention to researches of non-traditional bioenergy plants. The results of the paper will be useful for further research in energy and agricultural development.
\end{abstract}

Keywords: biomass utilization, biofuel, feedstocks, primary agriculture residue, secondary agriculture residue. JEL Codes: Q15, Q16.

\section{Introduction}

Biomass as a renewable resource is forestry crops and residues, agricultural crops and residues, sewage, industrial residues, animal residues, and municipal solid waste. Biomass is the only renewable energy not "freely" available (as opposed to wind and water) and has a long supply chain from planting, growing, harvesting, pre-treatment, and conversion (Rural Biomass Energy Book, 2020). Biomass cuts across several policy areas, including energy, agriculture, forestry, environment, land use, regional development, taxation, and trade. In addition to deforestation and wood processing waste but also a waste of agricultural production can be used for energy productions - straw and rapeseed, triticale, traditional agricultural herbs, and other crops are grown specifically for energy purposes. The specificity of bioenergy plants is evident not only in the production of biofuels but also in other types of energy - heat, and electricity.

Agriculture is one of the key players in the development of a Green Economy, creating a sector that distinguishes between two areas of bioenergy - biofuels (bioethanol and biodiesel) and bioenergy (biogas and solid biomass) for heat and electricity generation. Hence, biomass in its solid, liquid, and gaseous forms can be directly substituted for fossil fuels. Four decades before (1978 years), the first researches on energy herbaceous plants began in the United States (Zeng-Hui, Hong-Bo, 2010). In Europe, similar studies were studied a little later, about 1983. (Veenendaal et al., 2004).

Copyright (C) 2020. Published by Vytautas Magnus University. This is an open access article distributed under the terms of the Creative Commons Attribution Non-Commercial 4.0 (CC BY-NC 4.0) license, which permits unrestricted use, distribution, and reproduction in any medium provided the original author and source are credited. The material cannot be used for commercial purposes. 
However, until today the research into different types of plants to assess the energy value of their biomass remains relevant. Currently, the total annual production of biomass in the European Union has been estimated at roughly 1.8 billion tons (European Parliament, 2018). The available biomass sidestreams are estimated at 314 million tons for agriculture and forestry alone (Cabeza et al., 2019). The term "sidestreams" describes the parts of the raw material that are not used for the main products, such as tree branches and sawdust from timber production, or the parts of fish that cannot be sold as fillets and portions. The value generated by utilizing these side streams is what drives this green energy production trend. Lithuania has significant renewable energy resources that accumulate in forests, fields or municipal waste landfills. The total fuel potential of biomass should is 5,85 million tonnes in Lithuania. It would have to increase by phytomass about 12,3 percent in the agricultural land and forests.

The European Commission is proposing a new growth strategy European Green Course to make the European Union (EU) a modern, resource-efficient and competitive economy by 2050. there are no carbon or greenhouse gas emissions; economic growth is decoupled from resource use; and there shall not be anyone human or any places left aside in the EU. According to the targets and directions of the strategy of the European Green Course, the aim is to promote the potential of renewable energy sources for energy production. Reducing the energy system's dependence on fossil fuel is crucial for the successful implementation of change in 2030-2050. The main target is energy efficiency and the promotion of renewable energy.

The EU has succeeded in decoupling emissions from economic growth over the last three decades, with net GHG emissions falling by $25 \%$ between 1990 and 2019 while gross domestic product (GDP) grew by $62 \%$. However, if current policies were continued, the current targets would mean we only achieve a $60 \%$ reduction by 2050 . Today's Communication proposes an EU-wide net greenhouse gas (GHG) emissions reduction target of at least $55 \%$ by 2030 , compared to 1990 levels. This target puts the EU on a balanced pathway to reaching climate neutrality by 2050 . The economic recovery from the COVID-19 pandemic requires a massive boost of investment and doing so in line with the increased climate ambition will provide a short-term economic stimulus that can foster long-term sustainable growth (Communication of European Green Deal, 2019).

Most scientists carefully considering such as the utilization of the potential of biomass for energy production from agricultural resources. This is because the utilization of biomass resources for energy production by agriculture creates competition for the food industry. They argued that the production of growing biofuels from agricultural resources could cause food shortages in global markets. Too much agricultural land is used for biofuel production, too much grain and vegetable oil travels not to the table for food but to tanks of car fuel (Šateikis, 2006; Solovyeva, Nuppenau, 2012; McCormick, Kautto, 2013; Marciukaitis et al., 2016).

For these reasons, the aim is to reduce the "food gap" between the utilization of food crops and biofuels in bioenergy (Zeng-Hui, Hong-Bo, 2010). EU officials have decided to freeze the utilization of wheat, rapeseed, corn, and other crops for biofuel production at the current level of 5 percent. For food and energy security, many countries are promoting biofuel crops that can be grown on non-food land so that the two systems are complementary rather than competitive. The main debate is on the production and use of first-generation biofuels in the field of energy. Growing plants for biofuels is controversial because the land, fertilizers, and energy for growing biofuel crops could be used to grow food crops instead. In some parts of the world, large areas of natural vegetation and forests have been cut down to grow sugar cane for ethanol and soybeans and oil palm trees for biodiesel (U.S. Energy Information Administration, 2019). Because of limited arable land, the use of biomass for energy must be balanced against the need for food, materials, biochemicals, and natural forests. EU commission suggests 
looking for other alternative resources for biofuels, this is the utilization of nonfood sources such as waste and algae (Rural Biomass Energy Book, 2020).

Current liquid biofuels (bioethanol and biodiesel) are mainly produced from first-generation feedstocks (vegetable oils and corn sugar), and second-generation biofuels will be produced from perennial energy feedstocks (non-food, cheap, and abundant plant waste biomass) (Naik et al., 2010). In the near future, hydrogen gas could be produced from algae, bacteria, or artificial photosynthesis to create hydrogen engines. Hydrogen is a third-generation biofuel when it is produced from biomass by algae or microalgal enzymes. The biofuel is three time as larger in the water than the water footprint of fossil fuels, and its combustion produces only water, although a technological breakthrough is needed in the future to produce hydrogen economically.

The first generation of biofuel production has been based upon the conversion of the storage carbohydrates (sugars and starch) in the plants into fuel (Schubert, 2006). Oil from plants such as oilseeds has also been used, but the relatively low yields indicate that this is unlikely to be a sustainable source of fuel on a global basis. The first generation of biofuel also has large carbon and water footprints. This kind of biofuels is two to five times larger than the water footprint of fossil fuels. However, the first generation of biofuels produced from the use of storage carbohydrates from the edible parts of plants crops (including maize, sugar cane, rape, soybeans, and other bioenergy plants, creates the potential for direct competition between food and fuel production (Naik et al., 2010). Competition between biomass and food production can be reduced through technological innovations such as the production of second-generation biofuels. So, the second generation of biofuels under development is based on the conversion of the structural carbohydrates of the plant cell wall (Yuan et al., 2008). This avoids direct competition with food production and makes a much wider range of plants possible sources of biomass (Henry, 2010).

Second-generation biofuels include lignocellulosic biomass as a feedstock (woody crops, agricultural residues or waste, etc.). According to Wang et al. (2016), the demand for lignocellulosic biomass for the production of second-generation biofuels will increase in the next decade. One of the sources of lignocellulosic biomass is eternal herbaceous plants. Their biomass can be an alternative energy feedstock for the industry of the future, complementing traditional energy resources (Bentsen, Moller, 2017). The second generation of biofuels refers to a range of feedstocks (energy plants, such as miscanthus, switchgrass, agave, mustard, sweet sorghum, algae, coal waste, and others). These plants can be used to convert biomass to useful fuels by conversion technologies (pyrolysis, combustion, liquefaction and gasification) and refining technologies (chemical Fischer-Tropsch methods) (McKendry, 2002). For example, in 2012, the Switzerland company Clariant has been opened lignocellulose manufacture in Germany that can produce up to 1,000 tons from 4500 tons of straw.

Therefore, need strong political leadership and legislation to guide the shift from fossils to biofuels while avoiding competition with food production. So, it is one of the limiting factors for a growing bioeconomy is the availability of raw material. Even though materials can be regrown, they are far from unlimited. The trend of closing material loops in industry is based on the fact that increasing both the availability of raw materials and the efficiency of their use will create a competitive advantage (Nordic Council of Ministers, 2020).

Lithuania is an agricultural country, and part of the grown agricultural products, such as grain and straw, can be used for heat and biofuel production (Povilaitis et al., 2010). Lithuania has opportunities and resources to promote economic growth and increase competitiveness by exploiting the potential of biomass value chains, i.e. the production of wood, textile, and chemical products made from raw materials of biological origin, using bio-waste for the production of value-added products, including biogas and biofuels. It is argued by some that value created by bioenergy plants is more appropriate for high value-added industries such as the production of products based on industrial 
biotechnology for the food industry. However, the solutions-oriented to high-quality products would require more investment in research and development. By European horizon program in 2021-2027 is planned to invest 10 billion euros to bio-economy research and innovation. The target to achieve biomass resource utilization to higher value-added products is realistic, therefore it is necessary to create an ecosystem where members of the science sector get ready to meet representatives of biomass production and its processing (Kargyte, Matijosyte, 2020).

Research problem: what biomass energy yield could be created from agriculture residues.

Research aim: to assess the biomass utilization potential on energy from agricultural residue.

Research objectives: (1) to analyse the composition of agriculture residues and identify the statistical methods for estimating; (2) to present the research results biomass yield on energy analysis by primary and secondary agriculture residues.

\section{Materials and methods}

The study was conducted at the Vytautas Magnus University of Lithuania in 2020. The primary data for analysis was collected from the State Statistical Service of Lithuanian, Lithuanian Energy Institute, Renewable Energy Statistics, Lithuanian Biomass Energy Association, etc. This study gave us information about agricultural crops, waste straw, traditional and non-traditional energy crops. Additionally, we collected information about the cultivated area in thousand hectares, agricultural production tons per hectare, and product-residue ratio to crop in the research. Also, this research included activities that consist of studying the literature. This analysis gave us information about the potential estimation of the energy yield of biomass from agricultural residue. It was determined agricultural residues can be defined and evaluated as primary or secondary depending on their origin.

Primary residues are solid vegetal residues left in the field after harvest or pruning and manure. Secondary residues are the portion discarded during the processing phase (olive pits, nutshelling, etc.). Although they consist in a promising feedstock for bioenergy use and, in general, for EU bioeconomy, they are currently underutilized mainly because of logistics constraints and lack of incentives. They positively contribute to rural development, representing a possible income for farmers, and if used as bioenergy feedstock they contribute to climate change mitigation strategies (Bioenergy Europe Statistical Report, 2018). Table 1 presents a list of primary and secondary agro-biomass feedstocks along with technical requirements for harvesting, benefits of mobilization, and seasonality.

Table 1. Primary Agricultural Residues

\begin{tabular}{|l|l|l|l|}
\hline $\begin{array}{l}\text { Seedstocks } \\
\text { examples }\end{array}$ & Harvesting requirements & \multicolumn{1}{|c|}{ Benefits of mobilization } & \multicolumn{1}{c|}{ Seasonality } \\
\hline $\begin{array}{l}\text { Straw, corn } \\
\text { stover }\end{array}$ & $\begin{array}{l}\text { Existing agriculture } \\
\text { machinery (e.g., Baler) }\end{array}$ & $\begin{array}{l}\text { No additional land required, considerate } \\
\text { collection prevents pests, paying attention } \\
\text { not to decrease SOC. }\end{array}$ & $\begin{array}{l}\text { During crop harvesting } \\
\text { season }\end{array}$ \\
\hline Pruning & $\begin{array}{l}\text { Agricultural machinery, } \\
\text { usually modified for } \\
\text { pruning }\end{array}$ & $\begin{array}{l}\text { No additional land required, avoidance of } \\
\text { pests / diseases, avoidance of emissions } \\
\text { from open-field burning }\end{array}$ & $\begin{array}{l}\text { After the pruning season } \\
\text { (usually winter - spring) }\end{array}$ \\
\hline $\begin{array}{l}\text { Plantation } \\
\text { removal } \\
\text { wood }\end{array}$ & $\begin{array}{l}\text { Excavators, large } \\
\text { shredders, etc. }\end{array}$ & $\begin{array}{l}\text { No additional land required, clear-up of field } \\
\text { for new plantations, avoidance of disposal } \\
\text { costs }\end{array}$ & $\begin{array}{l}\text { At the end of an orchard's } \\
\text { lifetime }\end{array}$ \\
\hline
\end{tabular}

Source: Bioenergy Europe Statistical Report 2018

Regarding primary agricultural residues (PAR), the most important type of agricultural biomass available for bioenergy is straw. It is left after the harvesting of mainly cereals and other annual lignocellulosic crops. The parameters that affect the straw potential are the area of land covered by these crops and the amount of straw produced per hectare or tonne of crop. Other types of residues that should be included in the category of primary residues are the products of cultivation process (e.g., fruit 
trees pruning). The potential of primary residues could be reduced in case environmental and sustainability issues would be taken into account, like the remaining of residues on the agricultural terrain for recycling of nutrients (Biomass Energy Europe, 2010).

Primary residues generally should be collected from the fields and it to do is harder, while secondary residues to be collected released at a central processing facility (Table 2).

Table 2. Secondary Agricultural Residues

\begin{tabular}{|l|l|l|l|}
\hline \multicolumn{1}{|c|}{$\begin{array}{c}\text { Seedstocks } \\
\text { examples }\end{array}$} & Harvesting requirements & \multicolumn{1}{c|}{$\begin{array}{c}\text { Benefits } \\
\text { of mobilization }\end{array}$} & Seasonality \\
\hline $\begin{array}{l}\text { Pits and residues from } \\
\text { crushing from olive } \\
\text { shells/husks from seed/nut } \\
\text { shelling, grape marc. }\end{array}$ & $\begin{array}{l}\text { No additional technical } \\
\text { equipment; no additional } \\
\text { infrastructure }\end{array}$ & $\begin{array}{l}\text { By-product; no additional land } \\
\text { required; concentrated at processing } \\
\text { site (no collection costs); avoids } \\
\text { disposal costs (e.g., landfilling) }\end{array}$ & Year round \\
\hline
\end{tabular}

Source: Bioenergy Europe Statistical Report 2018

Also, the researchers suggest attention to non-traditional energy plants, which were grown in the Lithuanian climate zone, cultivation, preparation and utilization for solid biofuel: miscanthus, sida, sorghum, cup plant, seeder hemp ant others. The traditional energy plants can be described as a perennial herbaceous plants (perennial bunchgrass, orchard grass, tall fescue, sativa and others) (Jasinskas et al., 2014).

The Statistics Method - Primary Agricultural Residue (PAR) and Secondary Agricultural Residue (SAR) used in analysing biomass potential referred to the guidelines developed by Biomass Energy (Biomass Energy Europe, 2010). This method used statistical data based on land use, crop yields, crop production, and from the literature. Statistical data were then combined with the conversion factor, such as the yield per hectare, residues to crop factor, etc. In addition, the assumptions were carried out to determine the portion of biomass that can be used for energy production, by considering the needs for the land use for other purposes. The data used was data obtained from annual reports to the relevant agencies, including the Department of Agricultural, Department of Energy, and the Department of Statistics of Lithuania. This research included activities that consist of the studying the literature and analysing the data.

Primary agricultural residue $(P A R)$. The most important primary agricultural residues of available agricultural biomass for bioenergy was winter cereals, summer cereals, and raped straw. Parameters that influenced the potential of straw was the area covered by these plants and the amount of straw produced per hectare or per ton of plant. The theoretical method of annual crop residues was estimated based on the cultivated area and agricultural production (AP) in ton per hectare, for each species of plant and the average ratio between the product and the residue (PtR) (Papilo et al., 2017).

Theoretical potential of primary agricultural residues (THP_PAR) was calculated by:

$$
\text { THP_PAR }=\sum(\text { CAixAPixPtRixAvi })
$$

where THP_PAR is theoretical potential of primary agricultural residues (e.g., straw, stalks), in tons; CAi - the cultivated area for $i$-th crop, in hectares (ha); AP i - the agricultural production for the $i$-th crop, in tons per hectare ( $t$ ha $\left.{ }^{I}\right)$; PtRi - product-residue ratio for i-th crop; Avi - the availability of residues for $i$-th crop according current harvest system.

The energy value of biomass fuel is characterized by the thermal value, which is characterized by the heat of combustion. Then the potential of each PAR can be converted into energy units $60 \%$ of the straw values of the total grain biomass, using a low heating value of 13.63 to $14.63 \mathrm{GJ} \mathrm{t}^{-1}$ with a water content of about $15 \%$. This data was used according to the German agency "Fachagentur 
Nachwachsende Rohstoffe" data of research. Tons unit of the theoretical potential of agricultural residues was converted to energy units by multiplying the potential (in $t$ year $^{-1}$ ) with a lower calorific value of a particular residue $\left(\mathrm{GJ} \mathrm{t}^{-1}\right)$. The ratio of product-residue by plant species (PtRi) has amounted from 1 to 2. The availability of residues for i-th crop according to the current harvesting system (Avi) was assumed equal to 1 (Papilo et al., 2017).

Secondary agricultural residues (SAR) were generated and collected from companies that process agricultural plant parts harvested to produce the food / feed. In some European countries, the company must report the volume and utilization of residues they produce to the local statistics agency (Papilo et. al., 2017). However, if the direct statistics are not available, the methodology for assessment using the following equation:

$$
\text { Pti }=\sum(\text { Cri x PtSRi })
$$

where Pti is the theoretical potential of secondary agricultural residues of $i$-th crop (tons per year); Cri - the production quantity of $i$-th crop (tons per year); PtSRi - the ratio between products and secondary residues of $i$-th crop.

Then the potential of each SAR can be converted into energy units through multiplying the

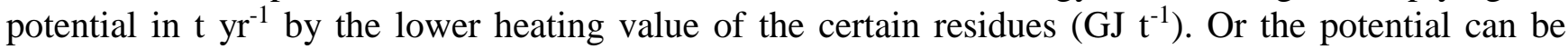

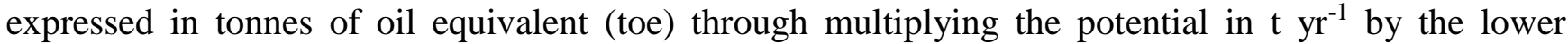
heating value of the certain residues $\left(\mathrm{GJ} \mathrm{t}^{-1}\right)$ and dividing it by the lower heating value of oil $\left(42 \mathrm{GJ} \mathrm{t}^{-1}\right)$ (Biomass Energy Europe, 2010).

\section{Results of Biomass Utilization for Energy Productions}

Biomass energy yield from agricultural residue depends on the type of raw material, its production and chemical composition, the country's agricultural development, and conversion technologies. The energy value of biomass from agriculture residue is described as an energy value, which is characterized by the heat of combustion. Plant biomass is usually burned as a solid fuel, creating heat energy. Biomass from agricultural residues, such as straw, can be used for other environmentally friendly purposes: biogas and biofuel production. Thus, agriculture cultivation procedures effectively increase biomass potential for energy production, and it was becoming increasingly important. According to research assumptions, about $40 \%$ straw is used for fodder, litter, horticulture and other purposes, and 60\% straw remains unused (Katinas, 2007). The ratio of straw to grain yield was dependent on the type and variety of plants, and it can vary from 1 to 2 (Table 3 ).

Table 3. Primary agricultural residue (PAR) utilization to biomass

\begin{tabular}{|c|c|c|c|c|c|}
\hline Source & $\begin{array}{l}\text { Type of } \\
\text { residue }\end{array}$ & $\begin{array}{l}\text { Product- } \\
\text { residue ratio } \\
\text { to crop }\end{array}$ & $\begin{array}{l}\text { Cultivated } \\
\text { area in } \\
\text { thousand } \\
\text { hectares } \\
\end{array}$ & $\begin{array}{c}\text { Agricultural } \\
\text { production tons } \\
\text { per hectare }\end{array}$ & $\begin{array}{c}\text { Agricultural } \\
\text { residues primary } \\
\text { in thousand tons } \\
\text { per year }\end{array}$ \\
\hline \multicolumn{2}{|c|}{ Total winter cereals } & 1.2 & 909.8 & 5 & 5458.8 \\
\hline Winter wheat & \multirow{4}{*}{ Straw } & 1 & 748.3 & 5.3 & 3966.0 \\
\hline Winter triticale & & 1.2 & 105 & 3.6 & 453.6 \\
\hline Winter rye & & 1.5 & 34.5 & 2.7 & 139.7 \\
\hline Winter barley & & 1 & 22 & 4 & 88.0 \\
\hline \multicolumn{2}{|c|}{ Total summer cereals } & 1.1 & 460.6 & 3.2 & 1621.3 \\
\hline Summer wheat & \multirow{3}{*}{ Straw } & 1 & 150 & 3.5 & 525.0 \\
\hline Summer barley & & 1 & 154 & 3.6 & 554.4 \\
\hline Summer triticale & & 1.2 & 10 & 3 & 36.0 \\
\hline
\end{tabular}




\begin{tabular}{|c|c|c|c|c|c|}
\hline Summer rye & & 1.2 & 0.5 & 1.4 & 0.8 \\
\hline Oats & & 1.3 & 95 & 2.6 & 525.0 \\
\hline Buckwheat & & 1.1 & 30 & 1.2 & 554.4 \\
\hline Cereals mixes & & 1 & 7 & 2.3 & 36.0 \\
\hline \multicolumn{2}{|c|}{ Total rape } & 2 & 276 & 3.2 & 1766.4 \\
\hline Winter rape & \multirow{2}{*}{ Straw } & 2 & 256 & 3.3 & 1689.6 \\
\hline Summer rape & & 2 & 20 & 1.6 & 64.0 \\
\hline
\end{tabular}

Source: formed by the author on the basis of publications of Sakalauskas (2012) and Papilo et al. (2017)

Table 3 results show, the total biomass straw potential from primary residues derived in 2020 years was about $8,846,5$ thousand tons per year. The highest potential winter cereals from primary residue were about 5458.8 thousand tons per year. The smallest potential summer cereals and rape from primary residue respectively was about 1621.3 and 1766.4 thousand tons per year.

According to the results, it can be notices the straw biomass potential from primary agriculture residue was about 5308 thousand tons per year (Table 4). Table 4 describes the assessment results of biomass energy potential derived from primary residues on three agricultural commodities. Based on the theoretical potential assessment, the highest winter cereals potential for primary agricultural residue biomass was about 53,210 thousand GJ (32.6\%). The smallest rape potential for primary agricultural residue biomass was about 17,218 thousand GJ (10.6\%) and summer cereals were about thousand. 15,804 GJ $(9.7 \%)$. The total energy output of 2020 years for primary agricultural residue biomass was about 163,178 thousand GJ.

Table 4. Potential energy yield by primary agricultural residue

\begin{tabular}{|c|c|c|c|c|}
\hline \multirow[t]{2}{*}{ Source } & \multirow{2}{*}{$\begin{array}{c}\text { Common } \\
\text { use }\end{array}$} & \multirow{2}{*}{$\begin{array}{c}\text { Agricultural residues } \\
\text { primary, thousand tons } \\
\text { per year }\end{array}$} & \multicolumn{2}{|c|}{ Energy yield (output) } \\
\hline & & & $\begin{array}{c}\text { thousand GJ } \\
\text { per year }\end{array}$ & $\begin{array}{l}\text { thousand GJ } \\
\text { per year }\end{array}$ \\
\hline \multicolumn{2}{|l|}{ Total winter cereals } & 3275 & $51323 \ldots 55096$ & 32.6 \\
\hline Winter wheat & \multirow{4}{*}{ bioethanol } & 2380 & $37288 \ldots 40029$ & 23.7 \\
\hline Winter triticale & & 272 & $4265 \ldots 4578$ & 2.7 \\
\hline Winter rye & & 84 & $1314 \ldots 1410$ & 0.8 \\
\hline Winter barley & & 53 & $827 \ldots 888$ & 0.5 \\
\hline \multicolumn{2}{|c|}{ Total summer cereals } & 973 & $15243 \ldots 16364$ & 9.7 \\
\hline Summer wheat & \multirow{7}{*}{ bioethanol } & 315 & $4936 \ldots 5299$ & 3.1 \\
\hline Summer barley & & 333 & $5212 \ldots 5596$ & 3.3 \\
\hline Summer triticale & & 22 & $339 \ldots 363$ & 0.2 \\
\hline Summer rye & & 1 & $8 \ldots 9$ & 0.01 \\
\hline Oats & & 193 & $3019 \ldots 3241$ & 1.9 \\
\hline Buckwheat & & 24 & $372 \ldots 400$ & 0.2 \\
\hline Cereals mixes & & 10 & $151 \ldots 163$ & 0.1 \\
\hline \multicolumn{2}{|l|}{ Total rape } & 1060 & $16607 \ldots 17829$ & 10.6 \\
\hline Winter rape & \multirow{2}{*}{ biodiesel } & 1014 & $15885 \ldots 17053$ & 10.1 \\
\hline \multirow[t]{2}{*}{ Summer rape } & & 38 & $602 \ldots 646$ & 0.4 \\
\hline & Total: & 5308 & $\begin{array}{c}157,391 \ldots \\
168,964\end{array}$ & 100 \\
\hline
\end{tabular}

Table 5 shows the potential of secondary biomass from agricultural residues consists of traditional energy crops and not-traditional energy crops. Bioenergy crop production is not allowed to compete with food crops, very important to prefer two categories of using crop energy in this subject: 1) surplus agricultural land, i.e. land that is not needed anymore for the production of food and feed crops or for other purposes; and 2) degraded or low productive land, i.e. land that is not suitable or no longer suitable for conventional commercial agriculture. 
Table 5. Potential energy yield by secondary agricultural residue

\begin{tabular}{|c|c|c|c|c|c|}
\hline Source & $\begin{array}{l}\text { Type of } \\
\text { residue }\end{array}$ & $\begin{array}{l}\text { Product- } \\
\text { residue ratio } \\
\text { to crop }\end{array}$ & $\begin{array}{c}\text { Agricultural } \\
\text { production tons } \\
\text { per hectare }\end{array}$ & $\begin{array}{c}\text { Cultivated } \\
\text { area in } \\
\text { hectares }\end{array}$ & $\begin{array}{l}\text { Agricultural } \\
\text { residues } \\
\text { secondary in } \\
\text { tons per year }\end{array}$ \\
\hline \multicolumn{2}{|c|}{ Traditional energy crops } & & & & 760,041 \\
\hline Legumes beans & pods/straw & 2.1 & 4.5 & 58658 & 554318 \\
\hline Pea & $\begin{array}{l}\text { stems } \\
\text { /leaves }\end{array}$ & 1.3 & 1.85 & 64428 & 154949 \\
\hline Lentil & $\begin{array}{l}\text { stems } \\
\text { /leaves }\end{array}$ & 1.7 & 0.9 & 40 & 61 \\
\hline Soybean & hulls & 2.5 & 2.2 & 2076 & 11418 \\
\hline Maize & stalk & 2.5 & 6 & 14.3 & 215 \\
\hline Sugar beet & leaves & 0.6 & 58 & 15.1 & 525 \\
\hline $\begin{array}{l}\text { Switchgrass (perennial } \\
\text { bunchgrass, tall fescue, } \\
\text { orchard grass, blue grass, ect.) }\end{array}$ & grass biomass & 1 & 2.5 & 4765 & 11913 \\
\hline Fibre hemp & \multirow{4}{*}{ stems } & 1 & 5 & 5275 & 26375 \\
\hline Linseed & & 0.3 & 0.37 & 782 & 87 \\
\hline Goat's-rue & & 1 & 0.35 & 206 & 72 \\
\hline Sativa & & 1 & 0.39 & 278 & 108 \\
\hline \multicolumn{2}{|c|}{ Non-traditional energy crops } & & & & 314,663 \\
\hline Sunflowers & hulls & 2.2 & 2.6 & 81 & 463 \\
\hline Miscanthus & $\begin{array}{l}\text { grass } \\
\text { biomass }\end{array}$ & 1 & 75 & 6 & 450 \\
\hline Jerusalem artichokes & $\begin{array}{l}\text { grass } \\
\text { biomass }\end{array}$ & 1 & 77.5 & 47 & 3643 \\
\hline Lupin & grains & 1 & 4 & 4263 & 17052 \\
\hline Millet & stalk & 1.83 & 1.75 & 132 & 423 \\
\hline Sorghum & stalk & 2.5 & 6 & 44 & 660 \\
\hline Honey clover & stems & 1 & 35 & 716 & 25060 \\
\hline Lucerne & hulls & 2 & 10.5 & 12708 & 266868 \\
\hline Serradella & stems & 1 & 2 & 22 & 44 \\
\hline & & Total: & & & $1,074,704$ \\
\hline
\end{tabular}

Source: formed by the author on the basis of publications: Fernandez, Batterham, 1995; Smil, 1999; Scholz et al., 2001; Žaltauskas, Ramoška, 2002; Yevich, Logan, 2002; Unal, Alibas 2007; Wright et al., 2009; Clarke et al., 2011; Sakalauskas, 2012; Iye, Bilsborrow, 2013; Alhassan et al., 2019

Biomass energy plants potential from secondary residues derived in 2020 years was about 1,075 thousand tons per year. The highest traditional energy plants potential from secondary agricultural residue biomass was about 760,041 tons per year. Non- traditional energy plants potential was about 314,663 tons per year.

This result shows Lithuania's agriculture has big potential biomass utilization for energy production. Also, we have to notice this result was estimated only cultivated and fertile land area. However, the potential of non-cultivated and infertile land areas for energy production has not estimated yet. Table 6 shows the potential energy yield by secondary agriculture residue in 2020 years. 
Table 6. Potential energy yield by secondary agricultural residue

\begin{tabular}{|c|c|c|c|c|}
\hline \multirow[t]{2}{*}{ Source } & \multirow{2}{*}{$\begin{array}{c}\text { Common } \\
\text { use }\end{array}$} & \multirow{2}{*}{$\begin{array}{c}\text { Agricultural } \\
\text { residues secondary } \\
\text { ton per year }\end{array}$} & \multicolumn{2}{|c|}{ Energy yield (output) } \\
\hline & & & GJ/yr & $\%$ \\
\hline \multicolumn{2}{|c|}{ Traditional energy crops } & Total: & 336,107 & 74.0 \\
\hline Legumes beans & bioethanol & 554318 & 251239 & 55.31 \\
\hline Pea & bioethanol & 154949 & 64500 & 14.20 \\
\hline Lentil & bioethanol & 61 & 25 & 0.01 \\
\hline Soybean & biodiesel & 11418 & 4903 & 1.08 \\
\hline Maize & bioethanol, biogas & 215 & 90 & 0.02 \\
\hline Sugar beet & bioethanol, & 525 & 223 & 0.05 \\
\hline $\begin{array}{l}\text { Switchgrass (perennial } \\
\text { bunchgrass, tall fescue, orchard } \\
\text { grass, blue grass, ect.) }\end{array}$ & biogas & 11913 & 4433 & 0.98 \\
\hline Fibre hemp & biodiesel & 26375 & 10583 & 2.33 \\
\hline Linseed & biodiesel & 87 & 36 & 0.01 \\
\hline Goat's-rue & biogas & 72 & 30 & 0.01 \\
\hline Sativa & biogas & 108 & 45 & 0.01 \\
\hline \multicolumn{2}{|c|}{ Non-traditional energy crops } & Total: & 118,125 & 26.0 \\
\hline Sunflowers & biodiesel & 463 & 221 & 0.05 \\
\hline Miscanthus & biogas & 450 & 204 & 0.04 \\
\hline Jerusalem artichokes & bioethanol & 3643 & 1395 & 0.31 \\
\hline Lupin & \multirow[t]{6}{*}{ biogas } & 17052 & 5980 & 1.32 \\
\hline Millet & & 423 & 176 & 0.04 \\
\hline Sorghum & & 660 & 268 & 0.06 \\
\hline Honey clover & & 25060 & 10575 & 2.33 \\
\hline Lucerne & & 266868 & 99289 & 21.86 \\
\hline Serradella & & 44 & 18 & 0.004 \\
\hline & Total: & $1,074,704$ & 572,356 & 100 \\
\hline
\end{tabular}

Table 6 describes the assessment results of biomass energy potential derived from secondary residues in two agricultural commodities. Based on the theoretical potential assessment, the highest potential of traditional energy plants from secondary agricultural residue biomass was about 336.1 thousand GJ (74.0\%). Non-traditional energy plants from secondary agricultural residue biomass were only used about 118.1 thousand GJ (26.0\%). The total energy yield for secondary agricultural residue biomass was about 572.4 thousand GJ.

\section{Conclusion}

The results of the research disclose biomass utilization from agricultural residues for energy production in Lithuania. The most important application is primary and secondary agricultural residues of biomass. Agricultural residues include crop residues remaining in fields after harvest (primary residues) and processing residues generated from the harvested portions of crops during food, feed, and fibre production (secondary residues). The results of the energy yield of biomass assessment show, the straw biomass energy potential from primary agricultural residues are higher than energy plant biomass from secondary agricultural residues. The biggest biomass energy yield from winter cereal straw was about 53,210 thousand GJ. The little less biomass energy yield from rape straw was about 17,218 thousand GJ, and summer cereal was about 15,804 thousand GJ. The total biomass energy yield from primary residue was about 163,178 thousand GJ. 
Compared with energy plants biomass potential from secondary agricultural residues the energy yield biomass potential is very small. This indicates the problems of the limitation of the research, analysis of comprehensive data, especially about non-traditional energy plant biomass, and their adaptation possibilities to cultivation in Lithuania. Was discovered that biomass energy yield from traditional plants was about 336,1 thousand GJ, and biomass energy yield from non-traditional energy plants was about 18.1 thousand GJ. The total biomass energy yield from energy plants was about 572,4 thousand GJ. It was discovered that biomass from primary residue is best to use for the production of bioethanol and biodiesel, and biomass from secondary residue is best to use for bioethanol, biogas, and biodiesel production.

We suppose that in order to solve the possibilities of increasing the biomass potential, it is necessary to increase the amount of biomass by optimizing plant growing technologies or searching for new, more productive plant genotypes. Less fertile, reclaimed land near roads and other polluted air objects could also be used for this purpose.

\section{References}

Alhassan, E. A., Olaoye, J. O., Olayanju, T. M. A., Okonkwo, C. E. (2019). An investigation into some crop residues generation from farming activities and inherent energy potentials in Kwara State, Nigeria IOP Conf. Series: Materials Science and Engineering. - https://iopscience.iop.org/article/10.1088/1757-899 X /64 0 / 1/012093/pdf [05 11 2020].

Bentsen, N. S., Moller, L. M. (2017). Solar energy conserved in biomass: Sustainable bioenergy use and reduction of land use change // Renewable and Sustainable Energy Reviews, Elsevier. Vol. 71: 954-958.

Bioenergy Europe Statistical Report 2018. Biomass for Energy: Agricultural Residues \& Energy Crops. - file:///C:/Users/vatan/Downloads/Factsheet_ABEC_web\%20(1).pdf [25 10 2020].

Biomass Energy Europe. Methods \& Data Sources for Biomass Resource Assessments for Energy (Freiburg-Germany: BEE). - file:///C:/Users/vatan/ Downloads/BEED7. 1ExecutiveSummary 2011-01-27.pdf [25 102020 ].

Cabeza, C., Gaffey, J., Hatvani, N., Hendriks, K., Lambrecht, E., Welck, H. (2019). Potential of biomass sidestreams for a sustainable biobased economy. AGRIFORVALOR - EU Horizon 2020 . https://www.researchgate.net/profile/Nora Hatvani/publication/338409459_Potential_of _biomass_s idestreams_ for_a_sustainable_bio-based_economy_ Bringing_ added_value_to_agriculture_an forest _sectors_ by_ closing_the_research _and innovation_ divide/ links/5e14ffc5a6fdcc28 3761a16e/Potential-of-biomasssidestreams-for-a-sustainable-bio-based-economy-Bringing-added-value-to-agriculture-and-forest-sectors-byclosing-the-research-and-innovation-divide.pdf [26 10 2020].

Clarke, S. Eng, P., Preto, F. (2011). Biomass Burn Characteristics factsheet. Order No. 11- 033. http://www.omafra.gov.on.ca/english/engineer/facts/11-033.pdf [27 10 2020].

Communication of European Green deal. - https://ec.europa.eu/info/strategy/priorities-2019-20-24 / european-green-deal_lt [26 10 2020].

European Parliament. Material use in the European Union: Towards a circular approach - Think Tank. European Parliament Think Tank. -https://www.europarl.europa.eu /thinktank/ en/document .html? reference=EPRS_BRI(2018)625180 [26 10 2020].

Fernandez, J.A., Batterham, E.S. (1995). The nutritive value of lupin-seed and dehulled lupin-seed meals as protein sources for growing pigs as evaluated by different techniques // Animal Feed Science and Technology. No.53, Vol. 3-4: 279-296.

Henry, R. J. (2010). Evaluation of plant biomass resources available for replacement of fossil oil // Plant Biotechnology Journal. Vol. 8(3): 288-293. https://www.ncbi.nlm.nih.gov/pmc/articles/PMC2859252/ [28 10 2020].

Iye, E. L., Bilsborrow, P.E. (2013). Assessment of the availability of agricultural residues on a zonal basis for medium- to large-scale bioenergy production in Nigeria // Biomass Bioenergy. Vol. 48: 66-74. 


\section{Management Theory and Studies for Rural Business and Infrastructure Development}

eISSN 2345-0355. 2020. Vol. 42. No. 4: 549-560

Article DOI: https://doi.org/10.15544/mts.2020.56

Jasinskas A., Sarauskis, E., Domeika, R. (2014). Technological evaluation of non-traditional energy plant cultivation and utilization for energy purposes in Lithuania // Proceedings International Conference of Agricultural Engineering, p. 1-8

Kargyte, V., Matijosyte, I. (2020). Prospects for bioeconomy development in Europe and Lithuania. Assessment of the factors of the economic downturn and low fossil fuel prices caused by the COVID-19 pandemic. - Vilnius: Lithuanian Association of Biotechnologists. - https://www.vdu.lt/wp-content/uploads/2020 /06/Bioekonomikos_perspektyvos_LBTA_2020_05_29_galut-1.pdf [26 10 2020].

Katinas, V. (2007). Volumes of energy production from renewable energy sources in 2008-2025 study preparation, p. 1-128. https://www.lsta.lt/files/studijos /2007/21_AEI_studija.pdf [26 10 2020].

Marciukaitis M., Dzenajaviciene E., Kveselis V., Savickas J., Perednis E., Lisauskas A., Markevičius A., Marcinauskas K., Gecevičius G., Erlickytė-Marčiukaitienė, R. (2016). Experience, significance and aspirations of the use of renewable energy resources in Lithuania // Energy. Vol. 62. No.4: 247267.

McCormick, K., Kautto, N. (2013). The Bioeconomy in Europe: An Overview // Sustainability. Vol. 5: 2589-2608. - file:///C:/Users/vatan/Downloads/sustainability-05-02589.pdf [07 11 2020].

McKendry, P. (2002). Energy production from biomass (part 2): conversion technologies // Bioresource Technology. Vol. 83: 47-54. file:///C:/Users/vatan/Downloads/ Energyproductionfrombiomasspart2\%20(1).pdf [10 11 2020].

Naik S. N., Goud, V. V., Rout P. K., Dalai, A. K. (2010). Production of first and second generation biofuels: A comprehensive review // Renewable and Sustainable Energy Reviews. Vol. 14: 578-597

Nordic Council of Ministers, 2020. https://pub.norden.org/nord2020 037/?mc_cid=ce580a8e2e\&mc _ eid= 74909 fe86a \#29890. [10 11 2020].

Papilo, P., Kusumanto, I., Kunaifi, K. (2017). Assessment of agricultural biomass potential to electricity generation in Riau Province. // International Conference on Biomass: Technology, Application, and Sustainable // Development IOP Publishing IOP Conf. Series: Earth and Environmental Science No. 65, 012006. https://iopscience.iop.org/article/10.1088/1755-1315/65/1/012006/pdf [27 10 2020].

Povilaitis V., Tilvikienė, V., Lazauskas, S., Kadžiulienè Z. (2010). Cereal bioenergetic potential in central Lithuania // Economics and Management: Current Issues and Perspectives. Vol. 3. No. 19: 103-109.http://www.su.lt/bylos/mokslo_leidiniai/ekonomika/2010_3_19_1/povilaitis\%20tilvikiene\%20lazauskas.pdf [27 $102020]$.

Raila A., Navickas, K. (2008). Biomass engineering. Kaunas: Academy, p. 1-284

Rural Biomass Energy Book 2020. Cleaner Energy Better Environment Higher Rural Income People's Republic of China. - https://www.adb.org/sites/default/files/publication/27997/rural-biomass-energy-2020.pdf [30 10 2020].

Sakalauskas, A. 2012. Substantiation of technology for harvesting and preparation of plant biomass (straw, grass, woody plants, etc.) for biofuel by dispersion. Alexander Stulginski University. p.1-107. https://zum.lrv.lt/uploads/zum/documents/files/LT_versija/Veiklos_sritys/Mokslas_mokymas_ir_konsultavimas/ Moksliniu_tyrimu_ir_taikomosios_veiklos_darbu_galutines_ataskaitos/SU2012mGBIOMASE.pdf [30 10 2020].

Sateikis, I. 2006. Potential of plant biomass cultivation and use for solid fuels and priority of research the present problems // Research papers of IAg Eng LUA \& LU of Ag. Vol 38. No 3: 5-21.

Scholz V., Krüger K., Höhn A. (2001). Environmentally compatible and energy - efficient production of energy plants // Agratechnische Forschung. Vol. 7. No. 4: 63 - 71.

Schubert, C. (2006). Can biofuels finally take centre stage. Nat // Biotechnol. Vol. 24:777-784.

Smil, V. (1999). Crop Residues: Agriculture's Largest Harvest Crop residues incorporate more than half of the world's agricultural phytomas //BioScience. Vol. 49. No. 4: 299-308.

Solovyeva, I., Nuppenau, E. A. (2012). Improving Measures for Targeting Agri-Environmental Payments: The Case of High Nature Value Farming. Paper prepared for the 126th EAAE Seminar, New challenges for EU agricultural sector and rural areas. Which role for public policy?file://C:/Users/vatan/Downloads/Improving_Measures_for_Targeting_Agri-Environmenta.pdf [05 11 2020].

U.S. Energy Information Administration. U.S. biodiesel production capacity declined slighty in 2019 https://www.eia.gov/todayinenergy/detail.php?id=45856 [06 11 2020]. 
Unal, H., Alibas, K. (2007). Agricultural Residues as Biomass Energy. Energy Sources, Part B. Vol. 2:123-140. - file:///C:/Users/vatan/Desktop/ES-BUnal_Alibas\%20residue\%20ratio.pdf [05 11 2020].

Veenendaal, E. M., Kolle, O., Lloyd, J. (2004). Seasonal variation in energy fluxes and carbon dioxide exchange for a broad-leaved semi-arid savanna (Mopane woodland) in Southern Africa, Global Change Biol. No. 10: $318-328$.

Wang, R., Balkanski, Y., Boucher, O., Ciais, P., Schuster, G. L., Chevallier, F., Tao, S. (2016). Estimation of global black carbon direct radiative forcing and its uncertainty constrained by observations. // Journal of Geophysical Research. Vol.121. No 10.

Wright, L., Boundy, B., Badger, P.C., Perlack, B., Davis, S. (2009). Biomass energy data book: edition 2. h u.s. department of energy. - ttps://www.co.shasta.ca.us/docs/libraries/resource-management-docs/spi-feir/3_ Exhibit_2.pdf?sfvrsn=a9006c9e_2 [07 11 2020].

Yevich, R., Logan, J. A. (2002). An Assessment of Bio-fuel Use and Burning of Agricultural Waste in the Developing World.. Submitted to Global Biogeochemical Cycles June 30, $2002 . \quad-$ http://www.as.harvard.edu/chemistry/trop/publications/yevich2002 .pdf. [07 11 2020].

Yuan, J. S, Tiller, K.H, Al-Ahmad, H, Stewart, N. R, Stewart, C. N. (2008). Plants to power: bioenergy to fuel the future. // Trends Plant Sci. Vol. 13:421-429.

Zaltauskas, A., Ramoska, E. (2002). Possible biomass fuel resources, their regional distribution in Lithuania. Ecostrategy, p. 8-15 .

Zeng-Hui, L., Hong-Bo, S. (2010). Main developments and trends of internationalenergy plants. Renew. // Sustainable Energy Reviews. Vol. 14: 530-534.

\title{
BIOMASĖS PANAUDOJIMO ENERGIJOS GAMYBAI IŠ ŽEMĖS ŪKIO ATLIEKŲ VERTINIMAS
}

\author{
Astrida Miceikiené $\dot{1}^{1}$ Rita Bužinskienè ${ }^{2}$ \\ ${ }^{1}$ Prof. dr. Vytauto Didžiojo Universitetas, Universiteto g. 10, Akademija, Kauno raj. Lietuva \\ El.paštas: astrida.miceikiene@vdu.lt \\ ${ }^{2}$ Doc. dr. Šiauliu Valstybiné Kolegija. Aušros al. 40, Šiauliai, Lietuva \\ El.paštas: r.buzinskiene@svako.lt
}

Santrauka

Straipsnyje analizuojamos biomasės panaudojimo energijos gamybai iš pirminių ir antrinių žemès ūkio žaliavų likučiu galimybès. Tikslas - ịvertinti biomasès panaudojimo potencialą energijos gamybai iš žemès ūkio atliekų. Tyrimui atlikti taikyti ịvairūs analizès metodai ir panaudoti ịvairių šaltinių duomenys.

Tyrimo rezultatai parodè, kad padidinti energijos gamybą galima naudojant šiaudų biomasę iš pirminių žemès ūkio žaliavų ir augalinę biomasę iš antrinių žemès ūkio žaliavų. Nustatyta, kad biomasès energijos išeiga iš pirminių žemès ūkio atlieku yra žymiai didesnè nei panaudojus antrines žemès ūkio atliekas. Tai padèjo atskleisti, kad Lietuvoje būtina skirti daugiau dèmesio ir paramos netradiciniu energiniu augalu tyrimu plètrai.

Raktiniai žodžiai: biomasès panaudojimas, biokuras, žaliavos, pirminès ir antrinès žemès ūkio liekanos.

JEL kodai: Q15, Q16. 